\title{
IAMJ
}

INTERNATIONAL

AYURVEDIC

MEDICAL JOURNAL

\section{CONCEPTUAL STUDY OF NIDRA AND ITS EFFECTS ON HEALTHY LIVING}

\section{Rachin Shivgotra}

Assistant Professor, Department of Kriya Sharir, Jammu Institute of Ayurveda \& Research, Nardani, Raipur (Bantalab) Jammu-181123, India

Corresponding Author: dr.rachin.shivgotra@gmail.com

https://doi.org/10.46607/iamj3108122020

(Published online: December 2020)

Open Access

(C) International Ayurvedic Medical Journal, India 2020

Article Received: 00/10/2020 - Peer Reviewed: 00/11/2020 - Accepted for Publication: 00/11/2020

Check for updates

\section{ABSTRACT}

Ahara, Nidra and Brahmacharya are the three main pyramids of life, which play vital role for maintenance of health in human being. In the Ayurvedic Literature, three factors i.e. Ahara, Nidra and Brahmacharya are compared with the triangles are termed as the three Upastambhas or Tripods. The inclusion of sleep in the three Upastambhas establishes its value. While explaining about Nidra, Acharyas stated that delight and sorrow, growth and wasting, strength and weakness, virility and impotence, the knowledge and ignorance as well as the survival of life and its termination depend on the sleep. The different theories stated regarding the phenomena Ayurveda regards Nidra (sleep) as one of the most essential factors responsible for a healthy and fulfilling life. Humans spend almost a third of their lifetime sleeping. ${ }^{1}$ Good sleep is essential and advantageous to the quality of life. A number of vital physiological changes occur during sleep. It is one of the Trayopastambhas mentioned by Acharaya Charaka. ${ }^{2}$ Sound sleep at night is a natural and nourishing phenomenon, so it is also called Bhutadhatri according to Acharya Sushruta ${ }^{3}$ (nourishes all living beings). Quality sleep is an indicator of good health as it is stress-relieving and normalizes bodily tissues. It is also called 'Vaishnavi maya'which provides nutrition to maintain good health like Lord Vishnu (the sustaining god), who nourishes and sustains this world. There are many concepts like Tridosha, Triguna, Panchmahabhuta, Lok Purusha Saamya such concept is Nidra (sleep). Triyaupstambha of body with Aahara and Brahamcharya. ${ }^{4}$ 
Keywords: Health, Nidra, Divaswapan, sleeping pattern

\section{INTRODUCTION}

When Mind is fatigued then sleep occurs. According to Howell, sleep is due to cerebral ischaemia. Cerebral cortex is the seat of higher centers like pre and post central gyrus \& associated area etc, which have the correlation with mental activities described in Ayurveda. So due to the reduction in cerebral blood supply Mind becomes calm that causes sleep. Sleep occurs when the seat of Chetana is covered by Tamas Guna (one among the Trigunas of mind which is responsible for ignorance) which predominates along with Kapha. When the mind along with the soul gets exhausted, or becomes stationary, and the sensory and motor organs also become inactive, the individual sleeps. Sleep is another form of tamas. Sleep manifests when tamas naturally predominates at night and the mind and intellect are in deep rest. Sleep occurs when Srotas get accumulated by Kapha and when the mind is devoid of contact with the sense organs because of fatigue.

\section{Types of Sleep}

In general sleep is classified into two types Swabhavika (natural sleep) and Aswabhavika (abnormal sleep). Acharya Charaka ${ }^{5}$ has described seven types of Nidra caused by Tamas vitiated Kapha mental exertion physical exhaustion Agantuka a complication of other diseases like Sannipataja Jwara (fever having involvement of Tridosha) and the very nature of the night (physiological sleep).

Acharya Vagbhata says that sleep occurring at night is considered normal while the remaining are abnormal.

Acharya Sushruta describes three types as: Vaishnavi (created by the sustaining god which is natural one); Tamasi and Vaikariki (due to diseases).

\section{Benefits of Proper Sleep}

Sukha (happiness), Dukha (unhappiness), Pushti (good physique), Karshya (emaciation), Vrushta (sexual power), Klibata (impotence),Gyan (knowledge), and Agyan (illiteracy), Jivita (long life), Ajivita (death) all these factors are depend on Nidra. Samyak Nidra gives us Sukha, Pushti, Bala, Vrushta, Gyan and Jivan. Asamyak Nidra causes Dukha,
Karshya, Abala, Klibata and Agyan. Like proper diet, proper sleep is also essential for the maintenance of good health. More than a periodic rest condition for the body and nervous system, sleep is a phase during which the body and nervous system can recuperate. Sleep plays a vital role in good health and well-being throughout life. Getting enough quality sleep at the right times can help protect mental health, physical health, quality of life, and safety. Happiness, proper nourishment, strength, virility, knowledge and, life itself depend on proper sleep. It improves growth, strength, vigor and complexion of the body. It increases the power of digestion, removes drowsiness and restores the natural equilibrium of bodily tissues. Proper sleep even enhances longevity in humans. During sleep, the body secretes hormones that help control appetite, energy metabolism, and glucose metabolism. Too little sleep disrupts the balance of these and other hormones. Sleeping excessively, or not at all, at improper times destroys happiness, health, and life like the goddess of death. For better knowledge, good sleep is essential. Human life itself is dependent on proper sleep.

\section{Appropriate Time for Sleep}

The ideal time for sleeping as mentioned in Kaiyadeva Nighantu is after the first two Yamas (approx 6 hours) of sunset. It is also advised that just before sleeping one should remember and pay respect to the god, sages and their teachers. Generally, for a healthy person, sleep occurs at night around the same time and lasts for a particular duration. Ayurveda regards this sleep as Ratrisvabhava Prabhavaja. It is further advised to avoid sleep during the first and last parts of the night and wake up before the sun rises.

\section{Duration of Sleep}

The amount of sleep required each day changes over the due course of lifespan. Although sleep interval varies from person to person.

Different age groups sleeping times are as under.

1. Amount of Sleep Newborn 16-18 hours a day

2. Pre-school-aged children 11-12 hours a day 
3. School-aged children At least 10 hours a day

4. Teens 9-10 hours a day

5. Adults (including the $7-8$ hours a day elderly)

The stage of childhood is explained as Kapha dominant and naturally produces more sleep which is required for proper growth and development. The middle stage of life is pitta-dominant and comparatively less sleep is required. Old age is Vata dominant and in this stage sleep duration naturally decreases.

\section{Modern Concept of Sleep}

During wakefulness, the brain is kept in an alert state by the interactions of two major systems of nerve cells, in the upper part of the pons and in the midbrain, which makes acetylcholine as their neurotransmitter (NT), sends inputs to the thalamus, to activate it. It in turn activates the cerebral cortex and produces a waking Electroencephalography (EEG) pattern. However, during Random Eye Movement (REM) sleep, the cholinergic nerve cells, thalamus \& the cortex are in a condition, similar to wakefulness but the brain is in Random Eye Movement (REM) sleep. The difference is supplied by three sets of nerve cells in the upper part of the brain stem: The nerve cells that contain the neurotransmitters. The brain stem cell groups that control arousal are in turn regulated by two groups of nerve cells in the hypothalamus. One group of nerve cells, in the ventrolateral pre-optic nucleus, contains inhibitory NT (neurotransmitter) and GABA. The major influence on sleep cycle is the body's circadian rhythm, the suprachiasmatic nucleus. These nerve cells in the hypothalamus contain clock genes, which go through a biochemical cycle of almost exactly 24 hours sleep, hormones and other bodily functions. The depth of sleep is not constant during the sleeping period but varies from hour to hour. In most adults, sleep deepens rapidly to the end of the first hour, after which it lessens sharply for a time, and then more slowly till the time of waking. Generally, sleep taken during the daytime is lighter than that during the night.

\section{Criteria of Better Sleep}

Ayurvedic texts have provided guidelines to enhance good sleeping. One should avoid sleeping on a bed that is not properly covered with sheets and pillows or is uneven or uncomfortably small. Avoid sleeping in the prone position. The bedroom should be clean, with clean bed linens. Comfortable bedding encourages quality sleep it provides good rest and happiness. The bed should stand at knee joint level, and the mattress should be soft and pleasant. At the beginning and end of night, i.e. while going to sleep and waking up, one should only think about virtuous acts and avoid all negative thoughts. Lying down in an easy posture on a comfortable bed removes the sense of fatigue, pacifies or soothes Vata dosha, brings sleep and Dhriti (lost recollection to the mind), and is aphrodisiac and conducive to the growth of the body conversely, lying down in a contrary manner is attended with contrary results. In hot climates, sleeping with a cool breeze is refreshing, keeps flies and mosquitoes away, arrests perspiration, removes the sense of fatigue, fainting and fits, and alleviates any burning, scorched or parched sensation. Samvahana (mild massage) is pleasant, soporific and aphrodisiac. It destroys the bodily Vata and Kapha doshas, removes the sense of fatigue and soothes the blood, skin and muscles. Sleeping on a cot mitigates all three Doshas (Vata, Pitta and Kapha), on a swing mitigates Vata and Kapha, on the ground makes the body stout and acts as an aphrodisiac, while on wooden planks increases Vata Dosha. In general sleeping on the ground is not preferred, and some authors opine that it causes great increase of Vata and dryness, but mitigates aggravation of Pitta and Rakta. One should not stay awake at night and sleep during the day. Performing both of these is injurious for health. One should observe moderation in sleep.

\section{Direction and How To Sleep}

While sleeping, one should position the head towards the east or south, but never towards the north. When traveling, also avoid positioning the head towards the west or north. Never position the legs towards teachers or any other respected person. Suppressing the Desire to Sleep Modern medicine has demonstrated that sleep has essential physiological functions, and sleep deprivation has deleterious effects on a number of bodily functions. Ayurvedic classics 
have clearly mentioned that one should never suppress the natural urge of sleep. Doing so causes delusion, excessive yawning, malaise, squeezing pain all over the body, drowsiness, lassitude, headache and heaviness in the head and eyes. All of these can be resolved with good sleep and mild massage.

\section{Health Risks Due To Irregular Sleep Pattern}

Sleep is an important determinant of life. Research has shown that both short sleepers and long sleepers are at an increased risk of all causes of mortality. Untimely, excessive sleep or prolonged vigil is like the night of destruction that takes away happiness and longevity. Improper sleep can also lead to Dukha, Karshaya, weakness, sterility or death. Improper sleep can produce Halimaka (severe form of jaundice), diseases of the head, stiffness and heaviness of the Jwara, Klama etc.

Sleeping in Purva (East) Medhavi (improves intellect) Sleeping in Paschima (West) Manasantapa (mental distress)

Sleeping in Uttara (North) causes Mrityu

Sleeping in Dakshina (South) Deerghayu (increases longevity)

\section{Diwaswapana Effects}

Sleeping during the day in any season except summer is not advised as it vitiates Kapha and Pitta Dosha, and makes the body more unctuous. Sushruta Samhita mentions that all the three Doshas are vitiated by day sleep. Kapha Dosha, when vitiated, results in dullness and heaviness all over the body and sleepiness. Vitiated Pitta Dosha causes an increased sensation of heat in the body and digestion related problems. Vitiated Vata Dosha causes dizziness and generalized body ache. Daytime napping is considered a normal part of the daily routine for babies and young children. However, some people continue to nap throughout their life. Every effort should be made to sleep at the proper time at night for the desired duration, and become habituated to it. If one remains awake at night due to non-habituation and unavoidable causes, then one should sleep for half of that period or for a period long enough to provide good rest during the following morning without having breakfast or eating any food.

\section{Nidra In Relation To Prakriti}

Vata Prakriti has dominance of Vata Dosha. Vata Dosha has Chala Guna so Vata Prakriti person like to travel. Vata Dosha has dominance of Vayu and Aakash Mahabhuta so Vata Prakriti person wants to move in sky. Dreams of dry, uneven and irregular water reservoir may be due to the Ruksha Guna.

Pitta Prakriti - Pitta Prakriti person sees gold, red coloured flowers like Karnikara, Palasa, forest fires, meteors, lightning, blazing, sun, flaming fire etc. in dreams. Pitta Prakriti has dominance of Pitta Dosha. Due to Ushna Guna of Pitta he sees fire, meteors, lightning etc. Gold, red color, fire, light etc. represents heat. Pitta has dominance of Agni Mahabhuta and Agni is source of heat so person of Pitta Prakriti usually like to think about fire.

Kapha Prakriti - Kapha Prakriti person sees dreams of seeing ponds and rivers full of water, lotus, lines of birds and clouds. In dreams he experiences lotus, swan, Cakravaka and beautiful lakes. Kapha Prakriti has dominance of Kapha Dosha. Due to Saumya Guna of Kapha person sees lakes, ponds etc. Birds, clouds may be representing Mridu Guna of Kapha. Lotus, swan etc. remain in

\section{Hazardous Effects Of Being Awake At Night}

Staying awake at night produces Rukshata in the body along with complications of vitiated Vata and Pitta Doshas and decreased Kapha Dosha. Vitiated Vata Dosha causes giddiness, stiffness all over the body, restlessness, lack of concentration and decision-taking power, excessive yawning, headache. Vitiated Pitta Dosha mainly causes digestion-related problems. Staying awake during the Pitta period (10-2 a.m.), causes delayed digestion where the consumed food is improperly digested initially, and later more completely by vitiated Pitta. The last part of the night (2-6 a.m.) is the period of Vata dominance and staying awake during this time completely disturbs the digestion process. It is critical to be asleep before this period begins to avoid major digestive problems. Not sleeping at night causes dryness in the body while, sleeping during the day increases the unctuousness in the body by increasing Kapha Dosha. Lack of adequate sleep can affect judgment, mood, and the ability to learn and retain information. It may also 
increase the risk of serious accidents and injury. In the long term, chronic sleep deprivation may lead to a host of health problems including obesity, diabetes, cardiovascular disease, and even early mortality.

\section{Causes of Anidra ${ }^{6}$}

In normal individuals, insomnia can be caused by the excessive elimination of Doshas from the body and head through Virechana (purgation) or Vamana (emesis), excessive worry, fear, anxiety, anger or grief, excessive smoke, physical exercise or sexual intercourse, bloodletting, fasting, uncomfortable bed, excessive work, old age or diseases, and especially due to the vitiation of Vata like colic pain, etc. Some are insomniac even by nature. Aggravated Vata and Pitta Dosha and depletion of Kapha Dosha are the main causes for loss of sleep.

\section{Management of Anidra}

If insomnia occurs for any reason, it can be immediately managed with Abhayanga, Snigdha, Snana, eating soup of domestic, marshy or aquatic animals, Shali rice (red variety of rice) with yogurt, milk, unctuous substances, alcohol, mental pleasure, pleasing fragrances, listening to enjoyable and relaxing music, Samvahana (mild massage), application of soothing ointment on the eyes, head and face, comfortable bed and home, and proper time.

\section{Sleep Patterns and Diseases}

Divaswapna is an etiological factor for Sthaulya (obesity), Kaphaja Jvara, kaphaja Arsha, Visarpa Vatarakta. Sleep in excess Cause of Antahvidradhi (internal abscess).

Sleeping in daytime and leads to Shiroroga keeping awake in night causes Nijashotha. Sleeping with face down leads to Mukha Roga (diseases of mouth).

Untimely sleep pattern Causes Ajeerna (indigestion). Comfortable sleep for a Prameha (group of urinary long-time disorders), Madhumeha (diabetes). Staying awake at night causes Kshaya (emaciation), Pratishyaya.

\section{Causes of Atinidra ${ }^{6}$ And Management}

When increased Kapha Dosha undergoes irregular processing, it obstructs the orifices of the tissues and causes heaviness of the body. From this, laziness develops and causes excess sleep. Excessive sleep should be managed by Vamana(emesis), Samshodhana (purification therapies), fasting therapy, bloodletting, nasal drops and by involving the person in strenuous mental activity or emotions like grief, anger and fear, all of which decrease Sleshma and thus lead to the reduction of sleep. Maharshi Charaka has mentioned that other than Samshodhana ${ }^{8}$, emphasis on increasing sattva guna $^{9}$ (mental purity) and suppressing Tamo guna.

\section{DISCUSSION}

Acharaya Charaka $^{10}$ regards Nidra (sleep) as one of the most essential factors responsible for a healthy and fulfilling life. Sound sleep at night is a natural and nourishing phenomenon. Good sleep is essential and advantageous to the quality of life. A number of vital physiological changes occur during sleep and help people stay healthy and function at their best. Quality sleep is an indicator of good health as it is stressrelieving and normalizes bodily tissues. Sleep is one of the four basic, natural instincts, and is considered as the pioneer for health; the remaining three being the desire to eat, drink and have sexual contact. Concept of Sleep When the mind along with the soul gets exhausted, or becomes stationary, and the sensory and motor organs also become inactive, the individual sleeps. So, an utmost importance should be given to Nidra for the maintenance of healthy body, mind and soul.

\section{CONCLUSION}

Sleep is directly connected with mental state. Ayurveda emphasized that Sharira and Satwa both interact with one another in all spheres of life. Sleep is particularly relevant to psychiatric illness and frequently part of diagnostic criteria for specific disorders. In today's era, people are not getting plenty hours of sleep because of busy life schedules and overload, as a result, work hours have engaged the time of sleep. Tension also contributes its share in reducing the sleeping time. If a healthy person not getting proper sleep, he will become a patient. It is not a serious problem in the start. But later on, stage it leads to number of health nuisance and ailments. In 
today's era Nidra is the very important factors to be studied. Nidra is a key factor to play a big role in our healthy life, In Current Scenario, due to heavy studies or heavy work schedule, Anidra is a big factor now a days. 5000 years back, Our Acharyas already told about Nidra, \& its maintenance, Ritu according Ahara and Vihara also explained and Acharyas also explained about Anidra, its causes, diagnosis and treatment. Susruta Samhita Classical Ayurvedic literature explains detailed descriptions of sleep and its beneficial effects on health, along with the negative consequences of improper sleep. Many of these facts have been proven with modern scientific research, more additional and research work should be done to understand the concept. Adopting the principles of Ayurveda and the guidelines for good sleep are the best ways to encourage healthy sleep and a healthy life.

\section{REFERENCES}

1. Kotur S B, A textbook of Ayurvedic physiology, page no. 343, (Chaukhambha Orientalia, Varanasi), 2nd edition, 2013

2. Sharma P V, Charak Samhita with text with English translation, Indriya sthana, ch. 5/42, pg no. 506 (Chaukhambha orientalia, Varanasi), 9th edition, 2005

3. Shastri A D, Sushruta Samhita of Maharshi Sushruta with Ayurvedatatwasandipika Hindi commentary, Sharirsthana, ch. 4/35, (Chaukhambha Sanskrit Sansthan, Varanasi), 2005

4. Gaur S K, Ayurvedic Sharir Kriya Vigyan, pg no 288, (Nath Pustak Bhandar, Rohtak), 5th edition, 1990

5. Sharma P V, Charak Samhita with text with English translation, Indriya Sthana, ch. 5/43, pg no. 506 (Chaukhambha Orientalia, Varanasi), 9th edition, 2005

6. Nidra And Nidranasha - An Ayurvedic Critical Review, P.G. Scholar of Samhita Siddhanta, Guide \& Professor of Samhita Siddhanta, International Ayurvedic Medical Journal.

7. Sastri H. Amarakosa. Varanasi: Choukhambha Sanskrit Samsthan. 2006, 1/7/36:110.

8. Brahmalinamuni Yoga Darshan Samadhi pada, 10. 6th ed. Varanasi: Choukhambha Sanskrit Samsthan. 2003, pg.40.

9. Sharma S. Mandukyopanishat, Jnanakhanda 108. 4th ed. New Delhi: Parimala Publication. 2005, pg.362.
10. Sharma R. Caraka Samhita Cakrapani Ayurveda Deepika. Sutra21/35, 1st ed. Varanasi: Choukhambha Sanskrit Samsthan. 2012.

\section{Source of Support: Nil \\ Conflict of Interest: None Declared}

How to cite this URL: Rachin Shivgotra: Conceptual Study Of Nidra And Its Effects on Healthy Living. International Ayurvedic Medical Journal \{online\} 2020 \{cited December, $2020\}$ Available from: http:/www.iamj.in/posts/images/upload/5382 5387.pdf 